\title{
MEMIKIRKAN MODEL PENDIDIKAN LITERASI BERBASIS KESURABAYAAN \\ UNTUK TAMAN BACA MASYARAKAT (TBM) DI SURABAYA
}

\section{THINKING OF A SURABAYA-BASED LITERATION EDUCATION MODEL FOR PUBLIC READING PARK (TBM) IN SURABAYA}

\author{
Nur Wulan ${ }^{1}$, Kukuh Yudha Karnanta ${ }^{2}$ \\ 1, Magister Kajian Sastra dan Budaya, Fakultas Ilmu Budaya, Universitas Airlangga \\ 2, Departemen Bahasa dan Sastra Inggris, Fakultas Ilmu Budaya, Universitas Airlangga \\ e-mail: kukuhyudha.karnanta@fib.unair.ac.id
}

\begin{abstract}
This community service program aims to develop a creative writing model based on Surabaya's local values. Surabaya's local values refer to identity and common worldview of 'arek Suroboyo' such as egalitarianism, urban, and multicultural. Those values are tied in the main theme a revitalization of Surabaya Identity. Participants are 115 junior high schools in Surabaya. The community service program is conducted through student-centered learning, while the strategies are discovery learning and project-based learning using inquiry technique. Learning materials are collected from archives such as photos, videos, and field trips to certain places. This community service program give a significant contribution to cultivating a cultural understanding of the Surabaya, as exposed in participants' literary works.
\end{abstract}

Keywords: creative writing, literacy, public library, Surabaya's local values

Program pengabdian pada masyarakat ini bertujuan untuk menginisiasi suatu model pendidikan literasi penulisan kreatif berbasis wawasan "kesurabayaan" di Taman Baca Masyarakat (TBM) Surabaya. Wawasan kesurabayaan yang dimaksudkan penelitian ini merujuk, namun tidak terbatas pada, identitas dan pandangan hidup masyarakat Surabaya yang egaliter, urban, dan multikultur, yang diterjemahkan dalam tema revitalisasi identitas dan sejarah Kota Surabaya. Partisipan program ini adalah 115 peserta yang duduk di Sekolah Menengah Pertama.. Metode pelaksanaan kegiatan dilakukan berbasis student-centered, strategi pembelajaran berupa discovery learning dan project based learning yang diiringi dengan teknik pembelajaran inquiry berupa tema Surabaya. Adapun media pembelajaran berupa foto, video, dan studi lapangan. Program ini berhasil memberi kontribusi signifikan terhadap pemahaman peserta didik pada Surabaya, yang tampak pada hasil tulisan-tulisannya.

Kata kunci: kesurabayaan, literasi, penulisan kreatif, taman baca masyarakat

\section{PENDAHULUAN}

Surabaya mencanangkan dirinya sebagai Kota Literasi, yang ditandai dengan dibuatnya prasasti "Surabaya Kota Literasi" yang ditandatangani Wali Kota Tri Rismaharini pada 2 Mei 2014. Hal tersebut diikuti dengan dibuatnya 1428 titik layanan baca, di mana 395 di antaranya terdapat di Balai RT/RW, dengan tenaga pendamping sejumlah 525 orang. Meskipun demikian, kuantitas TBM beserta tenaga pendamping tersebut kurang berkorelasi positif dengan Indeks Pembangunan Manusia Surabaya yang rerata kenaikannya kurang dari 1 digit. Dari hasil observasi di lapangan bahkan menunjukkan kurangnya tingkat partisipasi warga terhadap program-program pendidikan literasi yang digagas oleh Pemerintah Kota Surabaya. Dari kuota 60 siswa, hanya 29 siswa yang tertarik mengikuti program pendidikan literasi Kelas Menulis 2018. Pada 2019, ada 
kenaikan angka partisipasi yang signifikan dari kuota 60 siswa, peminatnya mencapai 115 siswa. Berdasarkan hasil observasi yang dilakukan pada taman baca masyarakat (TBM) di Surabaya, terdapat beberapa fenomena yang patut dijelaskan sebagai justifikasi pentingnya penelitian yang diajukan proposal ini.

Pertama, tidak meratanya kualitas sumber daya tenaga pendamping TBM. TBM di Balai RW Peneleh Surabaya dan Bangunrejo, misalnya, tidak memiliki program spesifik untuk menstimulus masyarakat di sekitarnya untuk terlibat dalam aktivitas literasi. Padahal, TBM Bangunrejo memiliki koleksi buku-buku yang terbilang sangat bagus, baik yang bergenre biografi, sastra, pengetahuan umum, dan bahkan bahasa asing. Namun, pendamping TBM tidak memiliki skill untuk menggunakan buku-buku tersebut sebagai media atau referensi dalam aktivitas di TBM-nya. Kedua, program atau aktivitas pendidikan literasi di TBM cenderung bersifat sporadis tanpa adanya visi yang jelas dan terukur. Hal tersebut diakui oleh tenaga pendamping TBM yang mengeluhkan tidak adanya satu program yang dipahami bersama sebagai suatu visi dan misi. Ketiga, belum adanya model pembinaan yang jelas dan berkesinambungan bagi para pendamping TBM untuk meningkatkan skill pribadinya sebagai garda depan pendidikan literasi di Surabaya.

Adapun terkait peserta didik, yang mayoritas siswa sekolah, terdapat beberapa fenomena yang perlu disampaikan. Pertama, pada program kelas mendongeng yang telah dan sedang dijalankan kurang bersifat interaktif, di mana tutor menjadi sentral, dan bukan siswa atau peserta. Tutor mendongeng secara lisan lalu diikuti oleh siswa atau peserta, namun tidak ada suatu luaran yang konkret dan berkesinambungan dalam program tersebut. Kedua, materi dongeng yang diberikan bersifat umum, yang boleh dikatakan tidak memiliki perbedaan signifikan dengan yang siswa dapatkan dari sekolah. Hal tersebut membuat peserta menjadi jenuh, yang diindikasikan dari jumlah peserta yang menurun di tiap pertemuannya. Hal yang sama terjadi dalam program kelas penulisan, di mana materi yang diajarkan adalah dongeng secara umum, yang merepetisi apa yang sudah didapatkan oleh peserta di sekolah. Ketiga, tutor yang mengampu program tersebut rata-rata berasal dari kalangan praktisi penulisan atau pendongeng, yang meskipun memiliki kemahiran dalam mempraktikkan keahliannya, namun belum memiliki kemampuan mengajarkan atau mentransfer kemampuannya pada peserta didik.

Berdasarkan fenomena-fenomena di atas, tujuan pengabdian pada masyarakat ini adalah untuk menciptakan model pembelajaran pendidikan literasi berbasis kearifan lokal bagi TBM di Surabaya yang mencakup pendekatan dan strategi pembelajaran ampuh, sehingga model pembelajaran dapat digunakan sebagai materi pembinaan pada tenaga pendamping TBM dan diaplikasikan pada (b) pembelajaran pada peserta didik program pendidikan literasi. Selain itu, program ini juga bertujuan untuk meningkatkan angka partisipasi dan aktivitas kegiatan khususnya dalam hal penulisan kreatif (cerpen, puisi, dongeng) pada peserta yang dilakukan berdasarkan model pendidikan literasi berbasis kearifan lokal kota Surabaya. Kearifan lokal yang dimaksud dalam proposal ini adalah identitas dan pandangan hidup masyarakat Surabaya yang egaliter, urban, dan 
multikultur, yang diterjemahkan dalam tema besar revitalisasi identitas dan sejarah Kota Surabaya.

\section{METODE}

Metode yang digunakan dalam program pengabdian ini adalah mixed method. Tahap pertama diawali dengan melakukan observasi lapangan dan wawancara kepada peserta/anggota taman baca khususnya dalam program menulis kreatif. Tahap kedua adalah pemberian materi kepada 115 peserta yang didapatkan secara proporsional sampling dari Surabaya utara, selatan, pusat, timur, dan barat. Pemberian materi dilakukan sebanyak delapan pertemuan menggunakan teknik inquiry yang berbasis pada student centered learning.

\section{HASIL DAN PEMBAHASAN}

Literasi merupakan salah satu aspek penting dalam tumbuh kembang suatu individu dan kualitas sumber daya manusia. Adapun pengertian pendidikan literasi di sini bukan sekadar mengacu pada aktivitas membaca dan menulis, melainkan juga mampu mengidentifikasi, menginterpretasi secara cermat, mengkritik, dan menciptakan sesuatu (kreasi). Richard Kern (2000) memberi definisi yang lengkap tentang literasi, yakni "The use of socially and historically and culturally situated practices of creating and interpreting meaning through texts. It entails at least a tacit awareness of the relationships between textual conventions and their context of use and, ideally, the ability to reflect critically on those relationships." Dari definisi tersebut dapat diambil pokok pikiran bahwa pertama, pendidikan literasi sesungguhnya suatu praktik multidisipilin ilmu yang di dalamnya memuat antara lain sejarah, budaya, dan sosial. Membaca dan menulis, dengan demikian, adalah contoh dari aktivitas, namun yang lebih penting adalah bagaimana praktik membaca dan menulis tersebut disituasikan dalam kondisi tertentu yang menstimulus seseorang untuk berkembang sesuai dengan konteks sosio-kultural tempat dia berada (Kemdikbud, 2017). Kedua, pendidikan literasi bermakna juga kreatif, dalam arti mampu membuat seseorang menciptakan sesuatu dari hasil pemahaman atau interpretasinya terhadap sesuatu. Prinsip ini penting ditekankan karena sering kali, tanpa disadari, pendidikan literasi termasuk di Surabaya, hanya mengedepankan pada aspek pemahaman namun tidak sampai pada penciptaan. Hal tersebut tercermin dalam beberapa penelitian terdahulu yang diuraikan berikut ini. Ketiga, pendidikan literasi juga seharusnya peka pada nilai-nilai kearifan lokal, dalam hal ini lokalitas Surabaya.

Penelitian berjudul Literasi Digital Remaja di Kota Surabaya yang ditulis oleh Qory Qurratun A'yuni (2015) melihat praktik penggunaan teknologi informasi pada generasi milenial di Surabaya. Penelitian tersebut bertujuan untuk mengukur tingkat literasi digital yang dimiliki dengan variabel penelitian aspek pencarian di internet, pandu arah hypertext, evaluasi konten informasi serta penyusunan pengetahuan. Metode penelitian yang digunakan adalah kuantitatif dengan responden adalah 99 remaja yang terdiri dari Mahasiswa S-1 Kampus B Universitas Airlangga, Siswa SMAN 4 Surabaya, SMA GIKI 2 Surabaya, SMPN 6 Surabaya, dan SMP Muhammadiyah 9 Surabaya. Hasil penelitian tersebut menunjukkan bahwa tingkat literasi digital remaja di Surabaya tergolong tinggi. Beberapa argumen kritis yang dapat diajukan terhadap 
penelitian itu adalah, pertama, pendidikan literasi digital yang dimaksudkan dalam penelitian itu adalah kemampuan mengenali konten informasi dalam platform digital saja, sedangkan dalam kenyataannya, platform digital hanya sebagian kecil dari pendidikan literasi secara keseluruhan. Kedua, penelitian tersebut belum memasukkan aspek kreatif, dalam artian tidak memandang pendidikan literasi sebagai suatu aktivitas aktif dan menghasilkan sesuatu. Padahal, seperti disebutkan pada bagian sebelumnya, kajian literasi harus menyentuh aspek penciptaan yang didasarkan pada pemahaman seseorang terhadap sesuatu. Ketiga, penelitian tersebut tidak memberikan dampak dan tindak lanjut apapun terhadap pendidikan literasi digital di Surabaya, karena bersifat sebagai laporan data kuantitatif.

Penelitian lainnya dilakukan oleh Rafi Ramadhan (2013) berjudul Analisis Aktivitas Pemberdayaan Masyarakat dalam Meningkatkan Minat Baca pada Komunitas Insan Baca. Penelitian bertujuan melihat bagaimana peran taman baca Insan Baca dan pemberdayaan masyarakat sekitar dalam meningkatkan kesadaran literasi masyarakat sekitar. Penelitian kualitatif ini sudah melihat aspek kreatif dan pelibatan kelompok masyarakat sebagai hal utama dalam pendidikan literasi. Hasil penelitian ini juga penting sebagai salah satu sample model taman baca yang layak dikembangkan. Meski demikian, sample taman baca harus diperluas dan dibandingkan agar mendapat gambaran yang lebih menyeluruh.

Penelitian ketiga adalah Taman Bacaan Berbasis Komunitas: Model Perpustakaan Mandiri Sebagai Salah Satu Bentuk Pemberdayaan Masyarakat Marjinal di Kotamadya Surabaya yang dilakukan oleh peneliti pada tahun 2015-2016. Pada penelitian ini, peneliti mencoba mengintegrasikan program Kuliah Kerja Nyata khususnya yang dilakukan oleh mahasiswa asing yang berkuliah di Universitas Airlangga, untuk terlibat dalam program di Taman Baca Nusantara yang berada di Kecamatan Rungkut. Penelitian ini menghasilkan satu temuan berharga bahwa integrasi program KKN pada aktivitas di TBM berdampak positif dan mendapat respons yang sangat baik dari warga. Keterlibatan langsung perguruan tinggi pada TBM bisa memunculkan rasa optimisme dan kepercayaan bahwa program tersebut dirancang dengan baik.

Penelitian ini merupakan upaya untuk melanjutkan dan mengonkretkan kajiankajian yang pernah dilakukan di atas. Distingsi dari penelitian ini nantinya adalah pertama, penelitian ini secara langsung bermitra dengan Dinas Perpustakaan dan Kearsipan Pemerintah Kota Surabaya, sehingga proses pengambilan data bisa lebih komprehensif; kedua, penelitian ini akan menghasilkan model pendidikan literasi yang bermuatan kearifan lokal masyarakat urban Surabaya, yang akan direkomendasikan untuk diimplementasikan pada seluruh TBM di Surabaya, bukan hanya secara parsial; ketiga, penelitian ini mengedepankan aspek kreatif atau penciptaan sebagai luaran utama, bukan sekadar identifikasi/deskripsi aktivitas pendidikan literasi.

Lebih jauh, sebagai kota yang semakin gencar melaksanakan modernisasi dan terdiri dari masyarakat beraneka kultur, Surabaya tentu memiliki keluasan potensi yang menarik untuk digali dalam aktivitas kreasi-literasi. Nama-nama kampung yang memiliki nuansa historis semisal Maspati, Keraton, Simolawang, Pulo Wonokromo, 
Sumur Welut, Kedung Doro, juga tokoh-tokoh legendaris seperti Sawunggaling, Sarip Tambak Oso, hingga Suster Gepeng, misalnya, adalah beberapa khasanah literer, dalam hal ini sastra lisan, yang menarik untuk dijadikan bahan penulisan kreatif. Kelisanan tersebut menjadi perlu dituliskan untuk kemudian didiseminasikan sebagai penanda dinamika proses sosio-kultural masyarakat urban Surabaya yang meskipun semakin bergerak ke arah megapolitan, namun tetap mengakar pada nilai-nilai sosiokultural dan historisnya. Dengan begitu, masyarakat bisa lebih memahami posisi, fungsi, dan perannya dalam perkembangan sosio-kultural di Surabaya dalam aktivitas pendidikan literasi yang berbasis pada wawasan kesurabayaan.

\section{Tentang 'Kesurabayaan'}

Program pengabdian ini terinspirasi dari pelaksanaan Kelas Literasi Menulis (KLM) yang diselenggarakan oleh Dinas Perpustakaan dan Kearsipan (Dispusip) Pemerintah Kota Surabaya. Pada tahun 2018, Dispusip bersinergi dengan Fakultas Ilmu Budaya Universitas Airlangga sebagai penyedia tutor. Saat itu, jumlah peserta sebanyak 29 peserta. Melalui program pengabdian pada masyarakat ini, program tersebut berlanjut pada 2019 dengan diikuti kurang lebih 115 peserta yang berasal dari siswa-siswi Sekolah Menengah Pertama di Surabaya. Diversitas asal sekolah sangat beragam mencakup wilayah barat, pusat, timur, utara, dan selatan, baik dari SMP negeri maupun swasta. Juga latar belakang agama dan etnis yang berbeda para peserta, sebagaimana karakter kebudayaan Surabaya yang multikultural. Ketersebaran asal sekolah tersebut sangat menggembirakan karena karya-karya yang terhimpun dalam buku ini bisa dikatakan, dalam derajat tertentu, cukup representatif untuk memberikan gambaran awal tingkat literasi menulis di Surabaya di tataran sekolah menengah. Juga, terkait dengan tema besar program ini yakni literasi tentang Kota Surabaya, buku ini merupakan ikhtiar awal edukasi tentang karakter masyarakat perkotaan berikut sejarah serta identitas kebudayaan yang mengitarinya, melalui penulisan baik karya fiksi maupun nonfiksi. Total terdapat 78 karya dengan rincian 36 puisi, 22 cerpen, dan 20 naskah pidato yang terhimpun dalam buku ini. Karya-karya tersebut berusaha diikat dengan satu tema yang juga sekaligus konsep dari program ini yakni "Kesurabayaan"

Pelaksanaan KLM di tahun 2019 ini didasarkan pada ide bahwa pendidikan literasi khususnya kepada anak berusia sekolah, pertama-tama dan yang paling utama, adalah menyasar wawasan dan pemahamannya atas hal-hal yang sangat dekat dan akrab dengan aktivitas sehari-harinya: keluarga, lingkungan sekitar rumah, sekolah, dan kota. Program KLM edisi tahun 2019 lantas menetapkan 'kota' sebagai tema dengan pertimbangan kota adalah latar hidup mereka sehari-hari yang, disadari atau tidak, membentuk karakter dan sudut pandang anak-anak tersebut secara ulang alik: kota, dalam hal ini Surabaya, telah memiliki riwayat, karakter, nuansa, dan dinamika yang jauh lebih panjang dari usia mereka. Kota dipahami bukan semata dalam perspektif geografis, melainkan juga suatu entitas yang senantiasa meremajakan diri dengan berbagai dimensi di dalamnya seperti budaya, ekonomi, agama, politik, dan sebagainya. Sebagai individu yang aktif dan berkembang, anak-anak itu juga berkontribusi pada perkembangan Surabaya di masa kini maupun di masa mendatang.

Istilah 'kesurabayaan' merujuk pada seperangkat nilai, praktik, dan kondisikondisi yang mengacu pada kota Surabaya sebagai latar sosio-kultural bagi para peserta 
dalam belajar dan beraktivitas sehari-hari. Adapun nilai-nilai mengacu pada skemaskema kesadaran yang didapat dari proses tertentu sehingga bersifat historis dan dinamis dalam arti bisa berubah sesuai tantangan zaman. Kesadaran tersebut bisa berupa, di antaranya, preferensi karya seni yang dikonsumsi, selera terhadap segala sesuatu yang menurutnya layak atau tidak layak diakrabi, kemampuan menafsir dan memaknakan suatu peristiwa, imajinasi, dan lainnya. Kesadaran tersebut bukanlah sesuatu yang terberi, melainkan didapat dari proses latihan dan pembiasaan yang tidak pernah selesai (Suyitno, 2012). Pada tahap inilah pendidikan literasi menjadi sangat penting sebab langsung beririsan dengan pembentukan kesadaran individu yang kelak akan menentukan praktik-praktik yang dipilih untuk 'diperjuangkan' seseorang sepanjang hidupnya.

Dengan kerangka berpikir sedemikian itu, tim pengajar KLM berusaha merancang suatu model pendidikan literasi yang 'ramah' bagi anak berusia sekolah khususnya menengah pertama, dengan capaian utama yakni peserta mampu menyusun karya tulis berdasarkan pemahamannya terhadap dinamika yang terjadi di kota Surabaya. Tentu, dengan porsi atau level yang disesuaikan dengan usia mereka.

\section{Model Pembelajaran}

Pendekatan student-centered diaplikasikan dalam model pembelajaran pendidikan literasi Program KLM 2019. Student-centered merupakan salah satu pendekatan yang mutakhir dalam meningkatkan keterlibatan dan motivasi para peserta didik (Williamson, 2008). Kemudian dilanjutkan dengan menggunakan strategi pembelajaran discovery learning yakni pembelajaran yang menekankan konsep pembelajaran secara mandiri untuk menemukan informasi terkait dengan materi yang diberikan di mana peserta didik akan didorong untuk menganalisis dan menyimpulkan dari suatu masalah (Sharma, 2005). Peneliti juga menggunakan strategi pembelajaran project based learning yakni pembelajaran yang menggunakan proyek sebagai media, peserta didik akan melakukan eksplorasi, interpretasi, dan sintesis untuk menyimpulkan pengetahuan baru berdasarkan pengalaman nyata (Benaer, 2012). Dalam penerapan strategi pembelajaran discovery learning dan project based learning, peneliti memberikan tiga tema utama sebagai teknik inquiry yang menjurus pada lokalitas Kota Surabaya. Teknik inquiry memiliki fungsi sebagai pemantik kemampuan peserta didik untuk mencari dan menyimpulkan materi (Rowsell, 2005). Tiga tema utama tersebut yakni Nostalgia Surabaya, yakni wawasan tentang sejarah Surabaya; Surabaya hari ini, yakni kepekaan tentang hal-hal aktual yang terjadi saat ini; serta Surabaya 2045, yakni visi tentang masa depan kota Surabaya.

Gambar 1 dan 2. Suasana di TBM Kel. Gentengkali dan Kel. Ambengan Sumber: Dokumentasi Peneliti
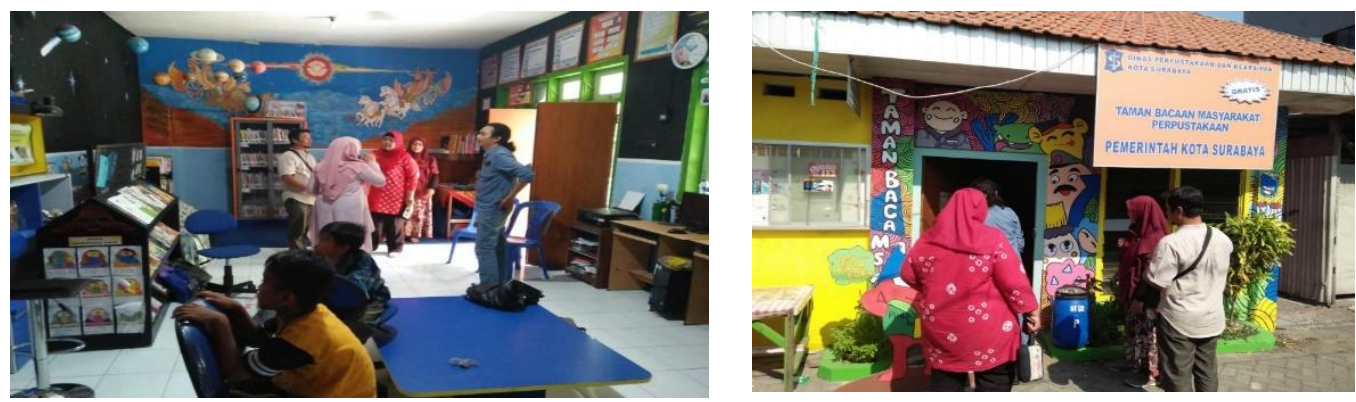


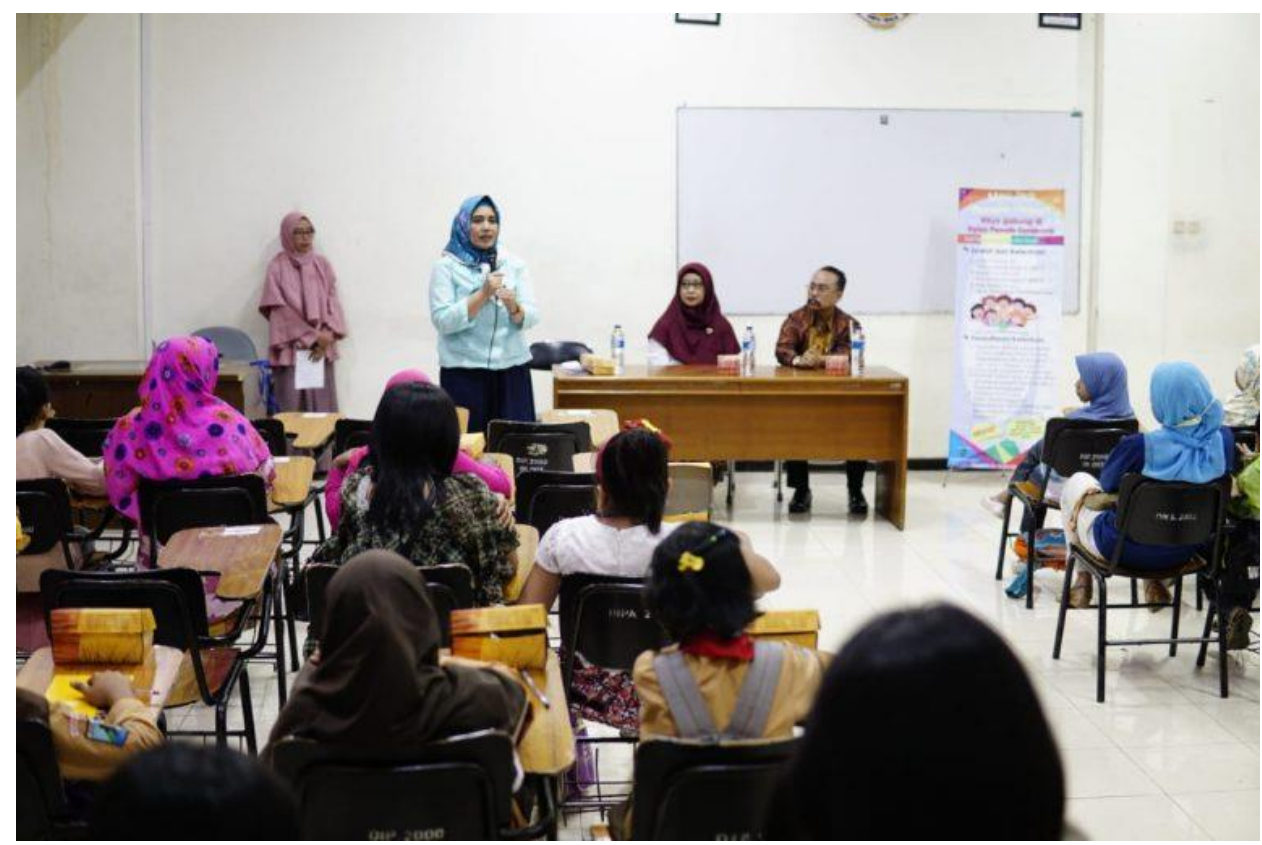

Gambar 3. Nur Wulan dan Kasi Dinas Perpustakaan dan Kearsipan Kota Surabaya saat membuka Program Kelas Literasi

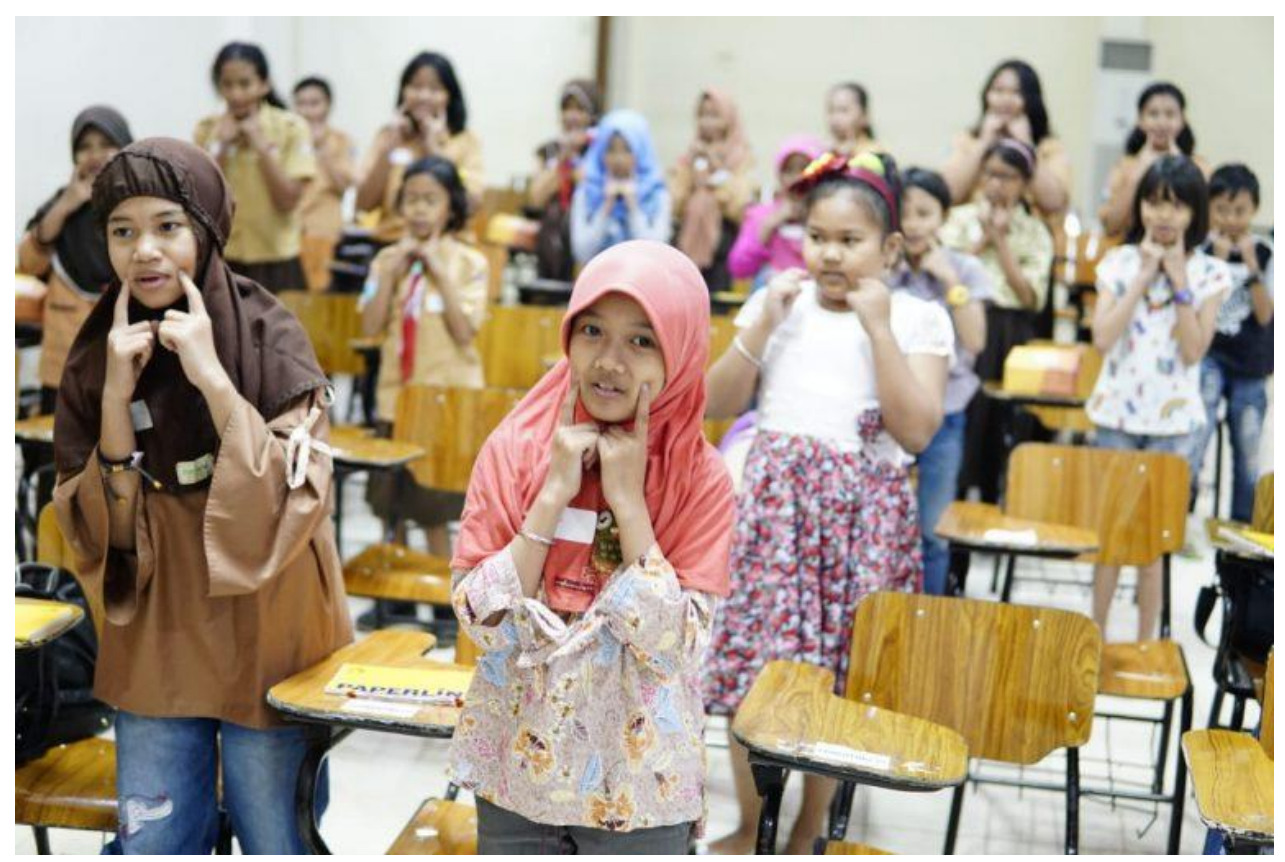

Gambar 4. Suasana Pelatihan di Kelas Literasi "Penulis Cilik" yang diadakan atas sinergi antara FIB Unair dengan Dinas Perpustakaan dan Kearsipan Kota Surabaya

Kondisi awalnya cukup mengejutkan, meski sesungguhnya sudah bisa diprediksi dari awal. Saat ditunjukkan foto-foto ikon-ikon Surabaya seperti Tugu Pahlawan, Kebun Binatang, Pintu Air Jagir, dan lainnya, peserta memang mengenalnya. Namun, hanya sekadar mengenal. Tidak lebih. Nyaris seluruhnya tidak mengenal 'makna' dari tempat-tempat ikonik tersebut, baik sejarah, kondisi terkini, dan apa pentingnya ikonikon tersebut. Maka, tidak heran bila 'lugu' dan 'polosnya' literasi peserta terhadap 
ikon-ikon di Surabaya masih tampak kuat dalam karya-karya yang ditulisnya. Misalnya pada puisi "Di Kebun Binatang Surabaya" karya Najwa Aulia Putri Ditia.

\section{Kebun Binatang Surabaya \\ Kau menjadi ikon di Surabaya \\ Terdapat patung Sura dan Buaya \\ Yang penuh dengan sejarah}

Dari satu bait tersebut bisa diketahui bahwa penulisnya mampu menangkap materi yang diberikan pengajar tentang bentuk puisi dan juga rima, misalnya. Namun, ekspresi yang dimunculkan masih datar dalam arti belum ada sesuatu yang 'menggugah' yang menunjukkan kedalaman pengetahuan penulisnya terhadap objek.

Soal menggugah rasa, puisi yang ditulis Gregorius Yansen berjudul "Nostalgia Surabaya" cukup menarik di simak. Tidak ada penanda konkret tentang Surabaya dalam puisi tersebut, namun penulisnya mampu menghadirkan suasana yang ngelangut.

Kenangan itu, satu per satu menguak rindu

Sepeda yang dulu menemani perjalanan kita, telah menjadi besi tua

Sudah tak mampu membopong kita menemui kota

Puisi-puisi lain dalam buku ini memang lebih mengarah pada "Nostalgia Surabaya", meski tidak sedikit juga yang lantas beranjak menuju kondisi kekinian. Ada ekspresi keluguan dan kepolosan, namun secara teknik dasar penulisan puisi, beberapa dari peserta mampu menampilkannya dengan baik.

Apabila puisi memang dirancang semacam 'merayakan masa silam', para peserta relatif bebas dalam cerita pendek. Hampir semua cerpen ditulis dengan latar waktu kekinian, tanpa ada rambu-rambu mereka mesti menulis dengan latar tempat Surabaya. Mengapa demikian? Pendidikan literasi memang harus terarah, namun tidak berarti peserta senantiasa 'diarahkan'. Ada beberapa momen di mana peserta bebas mengeksplorasi ide mereka ke dalam bentuk cerita. Fungsi tutor hanya memastikan bahwa aspek-aspek intrinsik suatu cerita pendek sudah terpenuhi. Dengan cara demikian pula akan diketahui bagaimana sesungguhnya cakrawala literasi mereka, preferensi bacaan serta selera mereka selama ini, yang tampak merembesi karya-karya ciptaan mereka sendiri.

Cerpen-cerpen dalam buku ini lantas menunjukkan kesadaran mereka yang memang khas remaja awal yang lahir di zaman 'milenial'. Ada yang bercerita tentang hobi sahabatnya yang menggandrungi K-pop, seputar kegiatan OSIS, persahabatan, keluarga, fabel, dan lainnya. Satu cerpen yang menyita perhatian adalah karya Natalia Putri Verdiana berjudul Sepucuk Surat Impian.

"Yu, ingat kita itu hanya inlander yang derajatnya tidak sama dengan mereka para Londo dan kamu itu juga seorang perempuan. Kamu hanya perlu mengurus urusan dapur saja!’ Seru bapak kepadaku.

Cerpen tersebut tidak hanya menunjukkan wawasan sejarah dari penulisnya, melainkan juga isu tentang stigma perempuan yang lebih banyak bekerja di sektor domestik rumah 
tangga. Teknik pemberian materi yang diberikan oleh tutor boleh jadi menstimulus imajinasi penulisnya untuk menulis cerita dengan latar waktu di era kolonial.

Naskah pidato menjadi tantangan tersendiri bagi peserta karena mereka dituntut untuk tidak sekadar berimajinasi, melainkan juga memprediksi bagaimanakah kelak wajah dan dinamika di Surabaya di masa mendatang. Tentunya, prediksi tersebut harus didasarkan pada apa yang sudah dipunyai Surabaya saat ini, dan juga sejarah yang telah terjadi di masa lampau. Beberapa teknik seperti membandingkan dengan kota di negara maju lainnya boleh dikatakan berhasil memicu daya kritis mereka. Simaklah petikan naskah pidato yang ditulis oleh Sayekti Putri berjudul Impian untuk Surabaya

Saya rasa teman-teman di sini seharusnya sudah tahu dan memiliki pola pikir yang bagus tentang bagaimana kita memperlakukan fasilitas dari pemerintah, terlebih yang baru dibuat, tapi, bagaimana dengan beberapa warga Surabaya yang terkadang masih "masa bodo" dan Bahasa Jawanya itu ... "mbohmbohan" soal perkembangan dan kemajuan kotanya

Keseluruhan naskah pidato tersebut tampak sangat fokus memaparkan kondisi terkini, permasalahan, perbandingan dengan kota lainnya di luar negeri, berikut pernyataan-pernyataan persuasif untuk memperbaiki Surabaya. Naskah-naskah pidato lainnya juga merekam visi anak-anak tersebut yang mengangankan Surabaya sebagai kota kebersihan, pendidikan, dan lainnya. Apabila kita sepakat dengan pernyataan bahwa masa depan suatu bangsa terlihat dari apa yang diperbuat oleh generasi mudanya saat ini, maka naskah-naskah pidato dalam buku ini menarik untuk disimak demi mendapatkan gambaran Surabaya di masa depan.

\section{KESIMPULAN}

Beberapa hal penting yang didapatkan dalam program pengabdian masyarakat adalah sebagai berikut, pertama, model pembelajaran pendidikan literasi yang berbasis kesurabayaan mampu meningkatkan angka partisipasi dari 29 peserta pada 2018 menjadi 115 peserta pada tahun 2019; kedua, model pembelajaran pendidikan literasi yang mencakup pendekatan berbasis student-centered, strategi pembelajaran discovery learning dan project based learning, dan teknik pembelajaran inquiry dapat memberikan wawasan kepada peserta mengenai Surabaya yang kemudian dituliskan ke dalam bentuk karya tulis; ketiga, penggunaan media pembelajaran berupa arsip foto dan video-video tentang Surabaya bisa menstimulus peserta, namun cenderung hanya sebatas pada tataran permukaan, dan masih membutuhkan strategi lain untuk pendalaman materi.

\section{UCAPAN TERIMA KASIH}

Terima kasih kepada Lembaga Pengabdian dan Pengembangan Masyarakat Universitas Airlangga yang telah mendanai kegiatan ini. Kegiatan ini mustahil berjalan lancar tanpa kesediaan jajaran pimpinan Dinas Perpustakaan dan Kearsipan Kota Surabaya.

\section{DAFTAR PUSTAKA}

Benaer, W. N. (2012). Project-Based Learning, Differentiating Instruction for 21st Century. United States of America: Sage .

Kemendikbud, TIM GLN. 2017. Panduan Gerakan Literasi Nasional. Jakarta: Kementerian Pendidikan dan Kebudayaan. 
Kern, Richard. 2000. Literacy and Language Teaching. New York: Oxford University Press

Qory Qurratun A'yuni, (2015) Literasi Digital Remaja Di Kota Surabaya: Studi Deskriptif Tentang Tingkat Kompetensi Literasi Digital Pada Remaja Smp, Sma Dan Mahasiswa Di Kota Surabaya. Skripsi, UNIVERSITAS AIRLANGGA. dst.

Rafi, Ramadhan. 2013. "Analisis Aktivitas Pemberdayaan Masyarakat Dalam Meningkatkan Minat Baca Pada Komunitas Insan Baca”. Jurnal Libri-Net. Vol. 2 / No. 2 / 2013.

Rowsell, K. P. (2005). Literacy and Education, Understanding the New Literacy. London: Paul Chapman Publishing.

Sharma, P. L. (2005). Discovery Teaching and Learning, Sarup Teaching Learning Series-4. New Delhi: Sarup and Sons.

Suyitno, Imam. "Pengembangan Pendidikan Karakter Dan Budaya Bangsa Berwawasan Kearifan Lokal”. Jurnal Pendidikan Karakter, Tahun II, Nomor 1, Februari 2012

Williamson, J. (2008). Literacy in the Student-Centered Classroom, A Practical Approach to Setup, Design, and Implementation. London: ROWMAN \& LITTLEFIELD EDUCATION.

Wulan, Nur. 2016. Taman Bacaan Berbasis Komunitas: Model Perpustakaan Mandiri Sebagai Salah Satu Bentuk Pemberdayaan Masyarakat Marjinal di Kotamadya Surabaya. Penelitian DIPA DITLITABMAS. Universitas Airlangga. 